\title{
Surgical Outcomes of Sialendoscopy-Assisted Approaches for Removal of Parotid Gland Stones
}

\author{
Yutae Jeon ${ }^{\mathbb{D}}$, Jihoon Choi ${ }^{\mathbb{D}}$, Juha Park ${ }^{\mathbb{D}}$, Young Min Park ${ }^{\mathbb{D}}$, and Jae-Yol Lim ${ }^{\mathbb{D}}$ \\ Department of Otorhinolaryngology, Gangnam Severance Hospital, Yonsei University College of Medicine, Seoul, Korea \\ 타액선 내시경을 이용한 수술적 접근법을 통한 이하선 타석증 치료 결과
}

전유태 · 최지훈 · 박주하 · 박영민 · 임재열

연세대학교 의과대학 강남세브란스병원 이비인후과학교실

Received July 12, 2021

Revised August 4, 2021

Accepted August 6, 2021

Address for correspondence

Jae-Yol Lim, MD, PhD

Department of Otorhinolaryngology,

Gangnam Severance Hospital,

Yonsei University

College of Medicine,

211 Eonju-ro, Gangnam-gu,

Seoul 06273, Korea

Tel $+82-2-2019-3460$

Fax $+82-2-3463-4750$

E-mail jylimmd@yuhs.ac
Background and Objectives With the introduction of sialendoscopy, minimal invasive surgery has become possible for the removal of sialoliths, although sialendoscopic removal of parotid stones remains a surgical challenge. Sialendoscopic stone removal can be differently applied according to the location and size of stones. This study was conducted to evaluate the surgical outcomes of sialaendoscopic stone removal and to provide a strategy for choosing an adequate surgical approach according to the characteristics of parotid stones.

Subjects and Method A retrospective study was conducted of 43 patients with parotid sialolithiasis who were treated by sialendoscopic stone removal between March 2017 and January 2021. Surgical techniques were classified into sialendoscopy alone (SA), sialendoscopy-assisted transoral approach (STO), and sialendoscopy-combined retroauricular approach (SRA). The parotid gland stones were categorized by size, location, and multiplicity.

Results Of the 43 patients, 13 patients underwent SA, 10 received STO, and 20 were treated with different SRA approaches. The SRA approaches included three distal, seven proximal, and ten intraglandular stone removal cases. The success rate of stone removal was $92 \%$ (12 cases) by SA, $90 \%$ ( 9 cases) by STO, and 100\% (20 cases) by SRA. In cases of SA and STO, all patients had distant stones except for one who had proximal stones. Postoperative complications including pain, swelling, wound dehiscence, sialocele, duct stricture, and facial palsy mainly occurred in cases treated with SRAs.

Conclusion Appropriate use of various sialendoscopy-assisted approaches is mandatory to preserve the gland and minimize surgical complications in patients with different features of parotid gland stones.

Korean J Otorhinolaryngol-Head Neck Surg 2022;65(5):276-82

\section{서 론}

타석증은 타액관에서 발생한 결석으로, 인구의 $1.2 \%$ 에서 발생한다. 타석의 $80 \%$ 는 악하선에, $19 \%$ 는 이하선에, $1 \%-2 \%$ 는 설하선과 소타액선에서 관찰된다. ${ }^{1)}$ 타석증은 식후 통증 및

This is an Open Access article distributed under the terms of the Creative Commons Attribution Non-Commercial License (https://creativecommons.org/licenses/by-nc/4.0) which permits unrestricted non-commercial use, distribution, and reproduction in any medium, provided the original work is properly cited.
부종을 유발하며, 일반적으로 식사 시에 증상이 악화된다. 반 복되는 이차 감염은 타액관의 협착과 실질의 위축을 유발한 다. ${ }^{2)}$ 타석의 치료는 타액선 마사지, 타액분비촉진제, 항생제 투여와 같은 보존적 치료가 우선시되며, 증상이 지속되는 경 우 수술적 치료를 고려한다. 악하선과 달리 이하선의 타석은 구강 내 접근을 통해 타석을 제거하기 어려운 경우가 많고, 구강 내 접근을 통한 제거가 어려운 경우 고전적으로 이하선 절제술을 시행하였다. 그러나 타석을 제거하기 위한 비침습적 
(non-invasive) 혹은 최소 침습적인(minimal invasive) 수술 방법이 발전해왔고, 특히 타액선 내시경술이 도입되면서 타액 관 내부로의 접근이 가능해졌고, 내시경만을 이용하여 타석 을 제거하는 술식의 성공률은 76\%-86\%로 보고되었다. ${ }^{3,4}$

그러나 여전히 타석의 크기가 크거나, 타석이 위치한 병변 부위가 타액선 실질 내(intra-glandular) 및 근위부(proxi$\mathrm{mal}$ )와 같이 깊은 경우 내시경만을 이용한 접근을 통해 제거 에 실패하는 경우가 있었고, 이에 McGurk 등은 내시경을 이용하여 타석의 위치를 확인하고 안면피부 절개를 통해 타 석을 제거하는 병할 술식(combined approach)을 보고하였 다. 후이개 절개를 통해 이하선에 접근하여 이하선관을 절개 하는 술식은 이하선을 보존하면서도, 크기가 크고 깊이 위치 한 타석을 제거할 수 있으며, 이하선 절제술에 비해 합병증의 빈도를 낮출 수 있었다. 그러나 이하선 및 이하선관 절개 후에 침샘종, 타액 누출, 감각저하, 흥터 및 안면마비의 발생이 보 고되어, 구강 내 접근을 통한 술식에 비해서는 합병증의 빈도 가 높게 나타났다. ${ }^{6.7)}$ 타석의 위치, 크기, 개수는 타석증의 적 절한 수술적 치료 방법을 선택함에 있어서 중요한 결정 요소 이며, 국내외의 연구에서 다양한 타석증의 치료 방법, 예후, 수술 후 합병증에 대한 연구가 진행되었으나, 대다수 악하선 을 중점적으로 다루기에 이하선 타석의 특성 및 분류에 따른 치료 방법 선택에 관한 연구는 드문 실정이다. 이에 본 연구 에서는 이하선 타액관 내 타석의 개수, 크기, 위치를 분류하 고, 다양한 타석제거술의 치료 결과 및 합병증을 분석하여 이하선 타석 제거에 있어 적합한 치료 방법을 선택하는 데 도움을 주고자 한다. ${ }^{8-10)}$

\section{대상 및 방법}

\section{대 상}

2017년 3월부터 2021년 1월까지 이하선 타석증으로 진단받 고, 타석 제거 수술을 시행 받은 43명에 대해 후향적으로 의 무기록을 검토하였다. 본 연구는 본원 기관생명윤리심의위원 회의 승인을 획득하여 진행하였다(IRB No. 2020-0677-001). 전산화단층촬영 $(\mathrm{CT})$ 에서 이하선관 내의 타석을 확인하여 타 석증을 진단하였다.

\section{타석의 분류}

본 연구에서는 타석을 위치에 따라 세 군으로 분류하였다. CT 영상의 축상면(axial view)에서 저작근을 절반으로 나누 면서 하악골을 수직으로 지나가는 가상의 선을 기준으로, 외 측일 경우 원위부(distal), 내측일 경우 근위부(proximal), 이 하선 실질 내에 위치하는 경우 타액선 실질 내(intra-glandular)로 분류하였다(Fig. 1). 만약 타석이 여러 개 관찰되는 경 우 구강 내로부터 가장 깊숙이 위치한 타석을 기준으로 위치 를 분류하였다. 타석의 크기는 최장경을 기준으로 측정하였 으며, 여러 개의 타석이 있는 경우에는 가장 큰 타석을 기준 으로 기술하였다.

\section{수술 방법}

타석의 제거는 전신마취하에 이루어졌으며, 내시경만을 이 용하여 제거한 경우, 내시경과 경구강 절개를 이용한 경우, 내 시경과 후이개 절개를 이용한 경우로 나누었다.

타액선 내시경만을 이용한 경우(Sialendoscopy alone, SA)

타석의 크기가 작고 타액관 내에서 비교적 자유롭게 움직 이는 경우에 시행하며, 바스킷(Stone Extractor; Karl Storz,
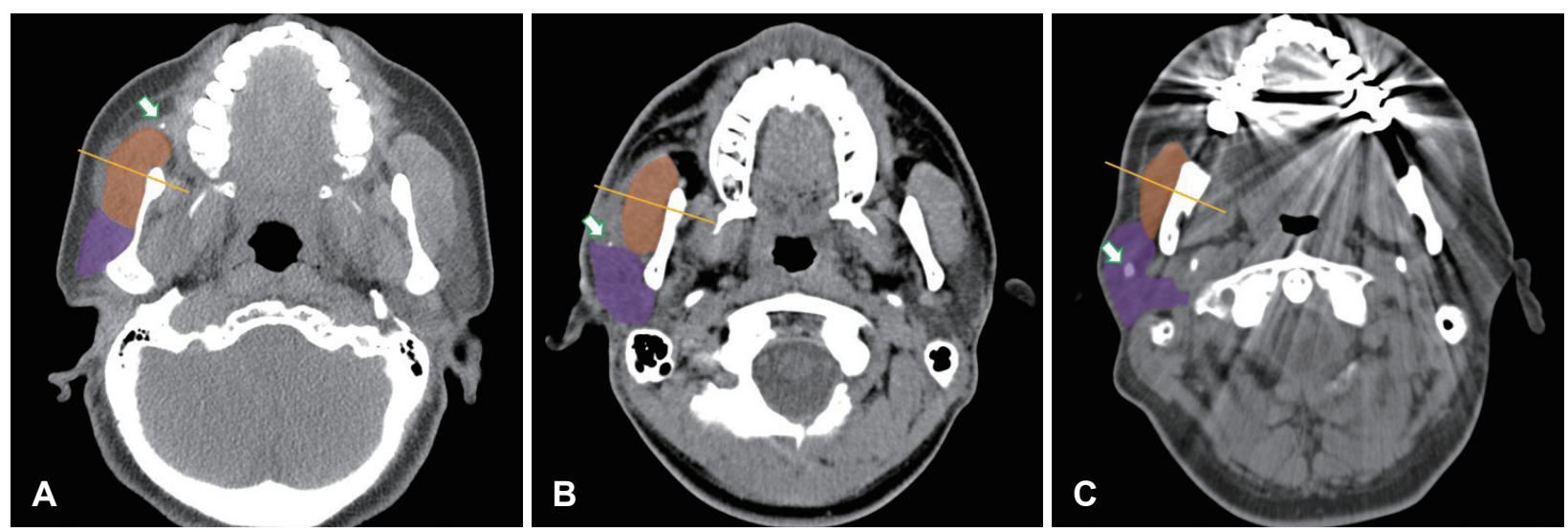

Fig. 1. Localization of parotid stones. A: Distal. B: Proximal. C: Intraglandular parotid stones. Green arrows indicate the location of parotid stones. Masseter muscles and parotid gland were colored in orange and purple, respectively. Distal and proximal stones were distinguished by an imaginary line perpendicular to the mandible, dividing the masseter muscle into half. 
Tuttlingen, German)을 이용하여 타석을 포착하여 제거한다 (Fig. 2). 타석이 개구부로 배출되지 않는 경우 개구부에 부 분절개(mini-papillotomy)를 시행할 수도 있다.

타액선 내시경과 경구강 절개술을 동시에 시행하는 경우 (Sialendoscopy-assisted transoral approach, STO)

타액선 내시경만으로 타석을 배출할 수 없는 원위부 타석 증의 경우 시행한다. 타액선 내시경을 이용하여 타석의 위치 를 특정하고, 이하선관 개구부위 주변 협부점막에 원형절개 를 가하고, 타액관을 박리하여 구강 내로 견인한 후 타석이 있는 부위의 이하선관에 절개를 가해 타석을 제거한다. 타액 관 및 협부점막의 절개부위는 흡수사를 이용하여 각각 봉합 한다.

후이개 절개 접근법과 타액선 내시경술을 병합하여 시행한 경우(Sialendoscopy-combined retroauricular

approach, SRA)

타액선 내시경을 통해 타석이 관찰되지 않는 근위부 또는 타액선 실질 내 타석과, 타석의 위치가 확인되나 구강 내 접 근법을 통한 제거가 어렵다고 판단이 되는 경우 시행한다. 내 시경을 통해 관찰되는 또는 추정되는 타석의 위치를 안면부 피부에 표시하고, 후이개 절개를 통해 이하선을 노출시키고, 이하선을 부분 절개하여 안면신경이 손상되지 않도록 주의 하며 타액선관을 박리한다. 타석이 있는 부위에 종절개를 가 한 후 타석을 제거한다. 절개된 타액선관 내로 내시경을 삽입 하여 타액관의 상태를 확인하고 잔존 타석을 제거하거나 부 유물을 세척한다. 타액관은 흡수사를 이용하여 봉합하고, 배 액관을 삽입하여 3-5일간 압박드레싱을 실시 후 배액관을 제 거한다(Fig. 3).

상기 모든 술식을 시행 후 구강을 통해 타액선 내시경을 삽 입하여 타액관 내에 타석 및 점액 덩어리(mucus plug)가 남 아있는지 확인한다. 식염수를 타액선 내시경 채널을 통해 주 입하여 도관 내 부유물을 세척한다. 타액관 협착을 예방하기 위해 구강 내로 배액관을 삽입하며 일반적으로 7-14일 후 배
액관을 제거한다.

\section{추적 관찰}

수술 날짜를 기준으로 1 주 후 외래에 재내원하였고 1 개월 간격으로 3 개월간 외래 추적 관찰 시행하였다. 내원 시 증상 호전 여부 및 합병증 발생 여부를 확인하였다. 합병증은 수술 후의 발생한 모든 이상반응을 포함하였으며 수술 부위 통증, 붓기, 침샘종, 타액관 협착, 수술 부위 벌어짐 및 안면마비 등 의 발생 여부를 평가하였다. 수술 3 개월째 침샘조영술(salivary gland scintigraphy)를 시행하여 수술 후 기능을 확인하 였고, 증상이 있는 환자의 경우에는 타액관 조영 자기공명영상 촬영(MR sialography)을 시행하여 협착여부를 확인하였다.

\section{결 과}

성별 분포는 남자 20명(47\%), 여자 23명(53\%)이었고, 연령 은 6세부터 89세의 분포를 보였으며, 평균 연령 43.8세였다. 타석의 발생은 좌측이 16예(37\%), 우측이 27예(63\%)이었고, 타석의 크기는 $1.0 \mathrm{~mm}$ 부터 $11.7 \mathrm{~mm}$ 까지 분포하였고 평균 크기 $4.4 \mathrm{~mm}$ 였다. 타석의 위치는 원위부가 25예(58\%), 근위 부가 8예(19\%), 타액선 내부가 10예(23\%)였다(Table 1).

타석의 제거 방법은 SA법을 통해 13명(30\%), STO법 10명 (23\%), SRA법으로 20명(47\%)의 환자를 치료하였다(Table 2). 잔존 타석 없이 타석 제거에 성공하고 수술 후 증상이 개선된 경우는 $\mathrm{SA}, \mathrm{STO}, \mathrm{SRA}$ 를 통해 각각 $92 \%, 90 \%, 100 \%$ 로 확인 되었으며 세 군의 통계적으로 유의한 차이는 없었다 $(p=0.307)$. 타석의 평균 크기는 $\mathrm{SA}, \mathrm{TO}, \mathrm{RA}$ 에서 각각 $2.6,3.3,6.3 \mathrm{~mm}$ 로 측정되었으며, 점차 커지는 경향성이 관찰되었으나 통계적 으로 유의한 차이는 보이지 않았다 $(p=1.183) .2$ 개 이상의 타 석을 제거한 경우는 $\mathrm{SA}, \mathrm{STO}, \mathrm{SRA}$ 에서 각각 1예(8\%), 3예 (30\%), 6예(30\%)였다. 타석의 위치에 따른 차이를 살펴보면, $\mathrm{SA}$ 를 통해 원위부 타석 12예(92\%), 근위부 타석 1예(8\%)에 대해 수술을 시행하였고, STO를 통해서는 모두 원위부의 타 석을 제거하였다. SRA를 통해서는 원위부 3예(15\%), 근위부
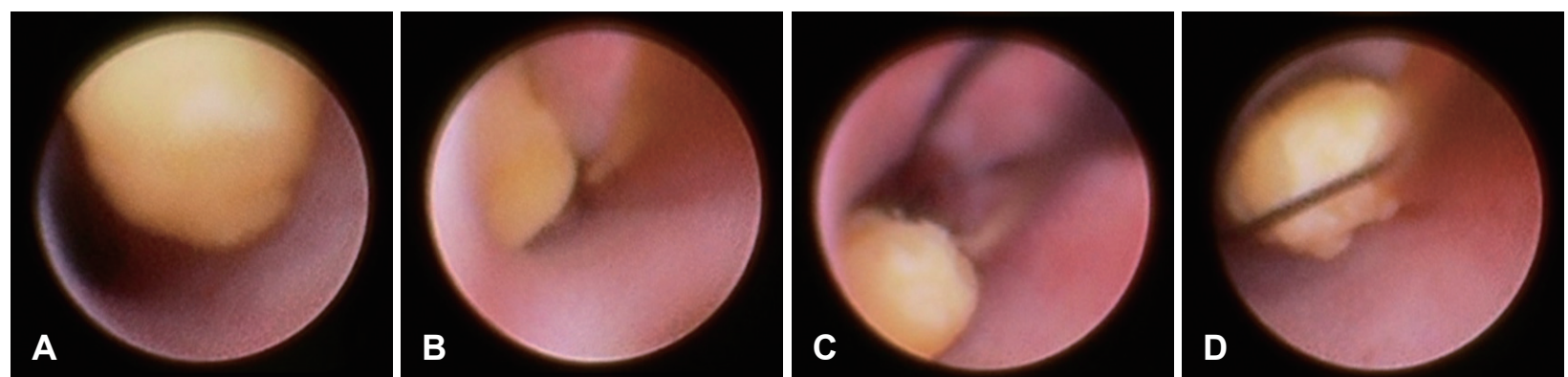

Fig. 2. Sialendoscopy alone approach. A: Distal floating stone. B: Inserting the basket. C: Opening the basket. D: Entrapment of the stone. 

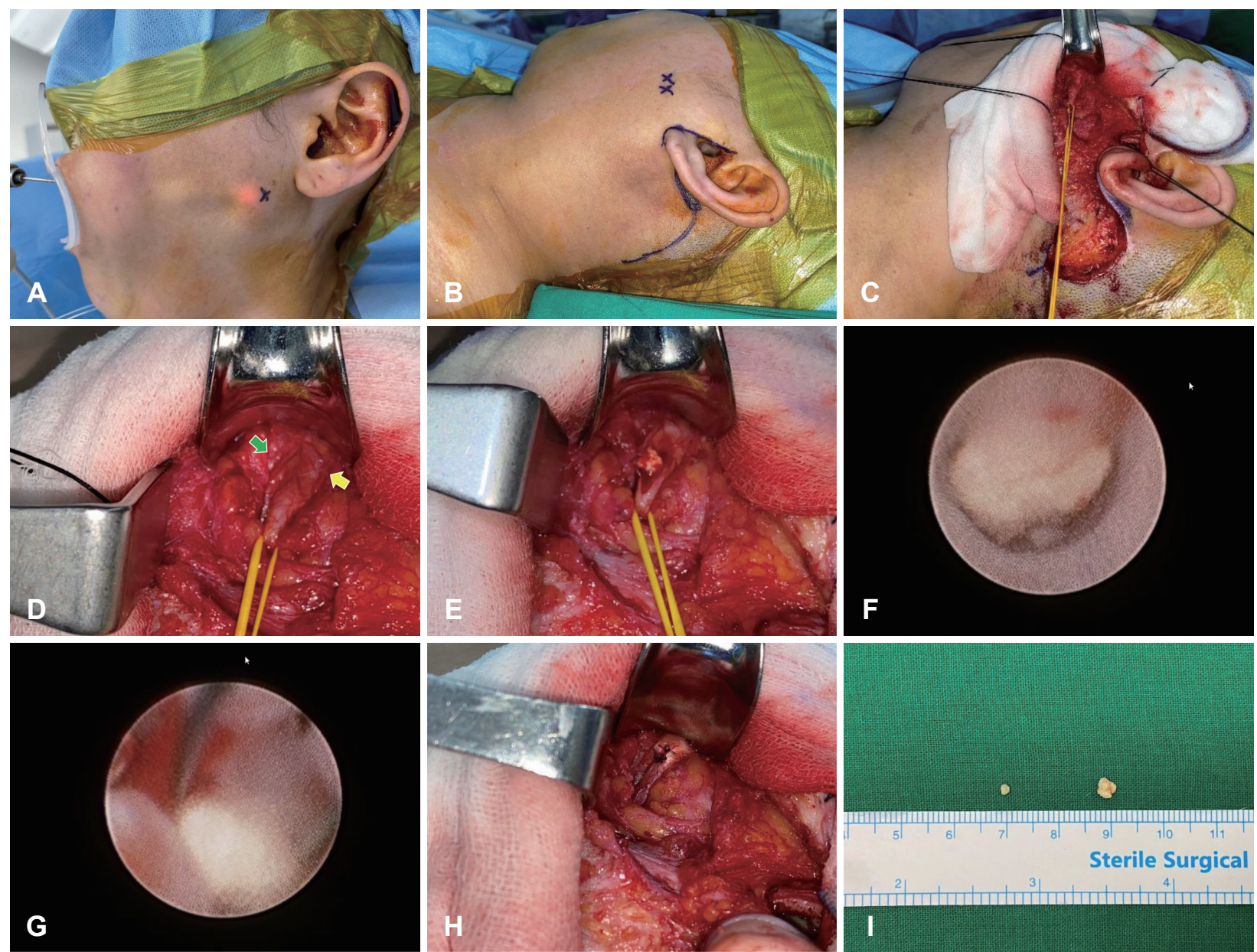

Fig. 3. Sialendoscopy with retroauricular approach. A: Localization of the stones using sialendoscope illumination. B: Modified facial lift incision designed. C: Elevation of the flap. D: Dissection of Stenson's duct. The yellow arrow points to the duct, and the green arrow points to the facial nerve's buccal branch. E: The stone was exposed after ductal incision. F: Sialendoscopy inserted through ductal incision site, another smaller stone was noted. G: A floating stone was grasped and removed using a basket. H: Ductal incision repaired. I: A picture of two stones removed.

Table 1. Demographic and clinical characteristics of the patient population $(n=43)$

\begin{tabular}{lc}
\hline \multicolumn{1}{c}{ Characteristics } & Value \\
\hline Sex & \\
Male & $20(47)$ \\
Female & $23(53)$ \\
Mean age, yr (range) & $43.8(6-83)$ \\
Site & \\
$\quad$ Left & $16(37)$ \\
Right & $27(63)$ \\
Mean length of stone, mm (range) & $4.4(1.0-11.7)$ \\
Localization of stones & \\
Distal duct & $25(58)$ \\
Proximal duct & $8(19)$ \\
Intraglandular & $10(23)$ \\
\hline
\end{tabular}

Data are presented as $\mathrm{n}(\%)$
7예(35\%), 타액선 내부의 타석 10예(50\%)를 제거하였다.

타석을 제거하는 데 실패한 경우는 2건이었고, 첫 번째 케 이스는 크기가 $1 \mathrm{~mm}$ 미만으로 작은 원위부 타석에 대해 $\mathrm{SA}$ 를 시도하였으나 타액관 내에서 타석이 관찰되지 않았고, 두 번째 케이스는 크기가 $1 \mathrm{~mm}$ 미만으로 작은 원위부 타석에 대해 내시경을 통해 접근하였을 때 타석이 관찰되었으나 타 석이 움직이면서 수술 도중 내시경 시야에서 사라지면서 제 거에 실패하였다. 두 번째 환자는 타액관 협착이 동반되어 있 어 타액관 성형술(sialodochoplasty)을 같이 시행하여 자연 배출을 유도하였다. 수술 후 타석 제거의 성공과 관계없이 장 기적으로 증상이 개선된 비율은 SA, STO, SRA를 통해 수술 받은 군에서 각각 $92 \%, 100 \%, 100 \%$ 로 관찰되었다(Table 2).

$\mathrm{SA}$ 를 통한 수술에서는 합병증이 발생하지 않았으며, STO 를 통한 수술에서 수술 직후 일시적인 붓기가 발생한 경우 1 예, SRA를 통한 수술에서는 붓기, 통증, 상처의 벌어짐, 타 
Korean J Otorhinolaryngol-Head Neck Surg I 2022;65(5):276-82

Table 2. Characteristics of parotid sialoliths $(n=43)$

\begin{tabular}{|c|c|c|c|}
\hline Characteristics & $\begin{array}{l}\text { Sialendoscopy alone } \\
\qquad n=13(30 \%)\end{array}$ & $\begin{array}{c}\text { Sialendoscopy-assisted } \\
\text { transoral approach } \\
n=10(23 \%)\end{array}$ & $\begin{array}{l}\text { Sialendoscopy-combined } \\
\text { retroauricular approach } \\
\qquad n=20(47 \%)\end{array}$ \\
\hline Mean longest diameter, $\mathrm{mm}$ (range) & $2.6(1.0-3.8)$ & $3.3(1.3-4.7)$ & $6.3(2.1-11.7)$ \\
\hline \multicolumn{4}{|l|}{ Stone count } \\
\hline Solitary & $12(92)$ & $7(70)$ & $14(70)$ \\
\hline Multiple & $1(8)$ & $3(30)$ & $6(30)$ \\
\hline \multicolumn{4}{|l|}{ Stone localization } \\
\hline Distal & $12(92)$ & $10(100)$ & $3(15)$ \\
\hline Proximal & $1(8)$ & $0(0)$ & $7(35)$ \\
\hline Intraglandular & $0(0)$ & $0(0)$ & $10(50)$ \\
\hline Success cases & $12(92)$ & $9(90)$ & $20(100)$ \\
\hline Complications & $0(0)$ & $1(10)$ & $8(40)$ \\
\hline Wound dehiscence & & & 1 \\
\hline Duct stricture & & & 1 \\
\hline Sialocele & & & 1 \\
\hline Swelling & & 1 & 2 \\
\hline Pain & & & 1 \\
\hline Facial palsy & & & 2 \\
\hline Median follow-up, day (range) & $113.5(13-196)$ & $139.9(12-476)$ & $151.1(35-421)$ \\
\hline
\end{tabular}

Data are presented as $\mathrm{n}(\%)$

액선관 협착, 침샘종, 일시적 안면마비의 합병증 등이 발생하 였다. 수술 후 평균 추적 관찰 기간은 SA, STO, SRA를 통한 수술에서 각각 113.5일, 139.9일, 151.1일로 나타났다.

\section{고 찰}

이하선 타석에 대한 고전적인 수술적 치료 방법인 이하선 절제술에 비해, 타액선 내시경의 도입과 함께 이하선을 보존 하면서 타석을 제거하는 최소침습적인 타액선 내시경술이 최 근에 대두되었다. 본원에서는 타액선 내시경만을 이용한 경 우와 타액선 내시경과 구강 내 절개를 동시에 시행한 경우, 타액선 내시경과 후이개 절개를 동시에 시행한 세 가지 수술 방법을 통해 이하선 타석을 제거하였다. 어떤 수술 방법을 택 할지 결정하는 데 있어서 타석의 크기, 위치, 개수는 매우 중 요한 요소이다. 일반적으로 타석의 크기가 작고 타액관 내에 서 쉽게 움직이는 경우 타액선 내시경을 이용하여 타석의 제 거를 시도하게 되며, 크기가 크거나, 도관 내 고정되어 유동적 이지 않은 경우 절개를 혼합한 접근법이 필요한데, 이는 타석 을 무리하게 움직이게 되면 타액관의 손상 및 협착을 유발할 수 있기 때문이다. 이때 원위부 타의석은 구강점막 절개를 통 해 접근하게 되며, 근위부 및 타액선 내부의 타석은 후이개 절개를 통해 접근한다.

평균 타석의 크기는 SRA가 $6.3 \mathrm{~mm}$ 로 가장 컸으며, STO 가 $3.3 \mathrm{~mm}, \mathrm{SA}$ 가 $2.6 \mathrm{~mm}$ 였다. $\mathrm{SA}$ 로 제거한 타석 중 가장
크기가 큰 것은 $3.8 \mathrm{~mm}$ 였다. $\mathrm{SA}$ 및 $\mathrm{STO}$ 를 통해서는 근위 부 1 건을 제외하고 전부 원위부의 타석을 제거하였다. 근위 부에 위치했던 1 건은 타석의 크기가 $1.4 \mathrm{~mm}$ 로 작고 내시경 을 통해 잘 관찰되고 움직임이 좋았기 때문에 내시경을 이용 하여 제거할 수 있었다. SRA의 경우 대부분 근위부 및 침샘 내부에 위치하고 크기가 큰 타석을 제거하였다. 원위부에 위 치했던 3건은 원위부와 근위부의 경계 근처에 위치했었고 외 부에서 피부를 통해 타석이 촉진 가능했었기 때문에, 후이개 접근법을 통해 제거하는 것이 유리했다. 수술을 통해 타석을 제거하지 못했던 2예 중 1 예는 증상 재발 시 재내원하기로 하 였으나 이후 방문하지 않았으며, 다른 1 예는 수술 중 타액관 성형술을 시행하였고, 외래에서 증상을 확인하였을 때 수술 전보다 호전되었다. 수술 도중 시야에서 사라졌던 타석이 넓 어진 타액관을 통해 자연 제거되었을 것으로 추정된다.

$\mathrm{SA}$ 나 $\mathrm{STO}$ 에서는 거의 합병증이 발생하지 않았고, SRA에 서 대부분의 합병증이 발생하였다. 수술 부위의 붓기나 통증 은 모두 일시적이었으며 2주 이내에 소실되었다. 타액관의 협 착 및 타액종은 수술 후 시행한 타액관 조영 자기공명영상촬 영(MR sialography)에서 발견되었으나, 환자의 주관적인 증 상은 수술 전에 비해 호전되어 타액선 마사지와 같은 보존적 치료를 시행하면서 경과 관찰하였다. 안면마비는 2예에서 관 찰되었으며, 1 건은 수술 후 2 일째에 발생하여 2달 뒤 완전히 회복되었으나, 다른 1 건은 침샘 조직 내 유착이 심하였으며 수술 중 안면마비 손상이 발생하여 수술 직후 하우스-브랙만 

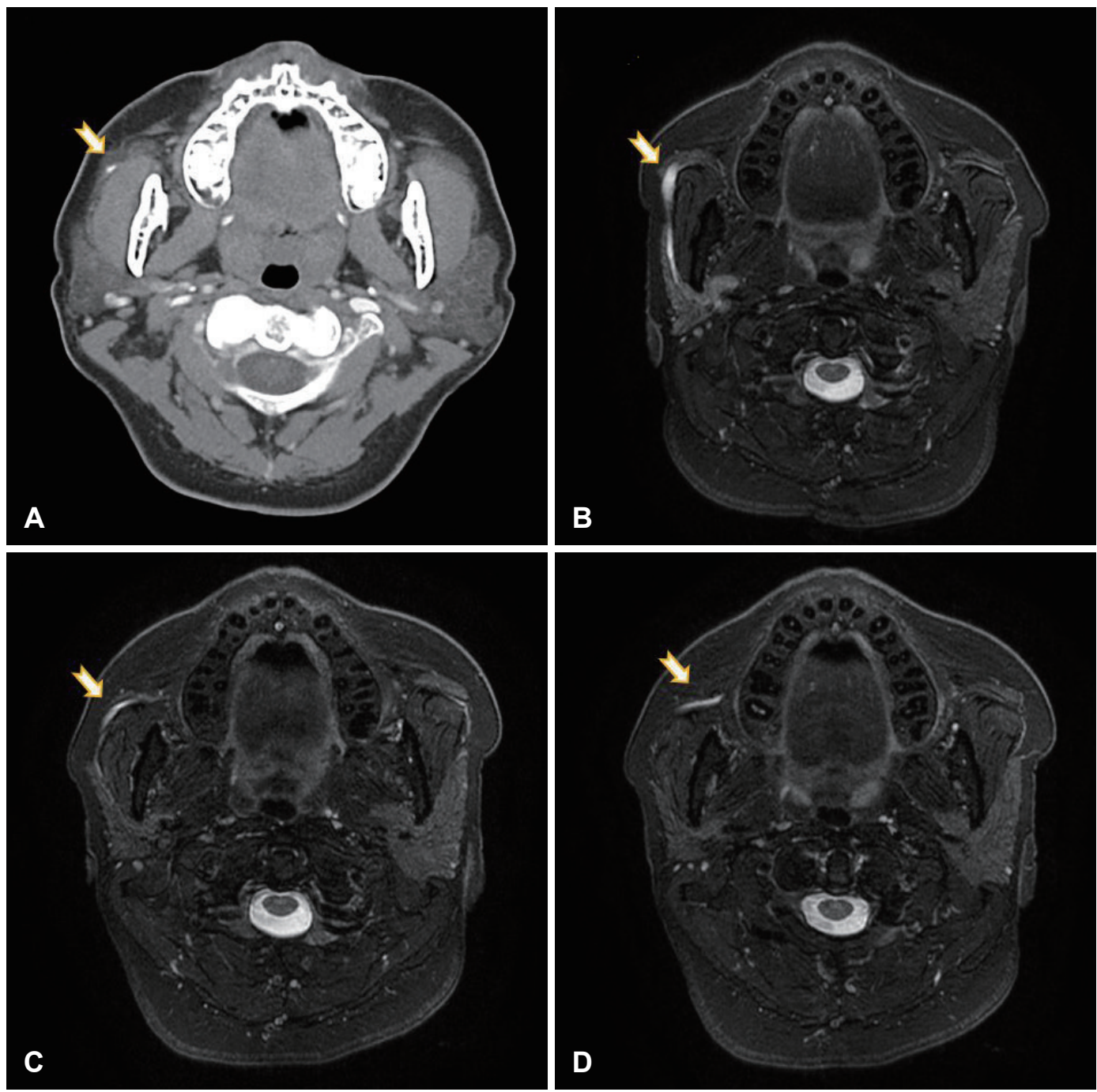

Fig. 4. Pre- and postoperative radiological findings. A: Preoperative CT image. Arrow indicates parotid duct stone. B: Preoperative MR sialographic image. Dilatation of the parotid duct (arrow) secondary to ductal obstruction by parotid duct stone. C and D: Postoperative MR sialographic images. Arrows indicate improvement of ductal obstruction and restoration of salivary flow after sialendoscopic stone removal.

(House-Brackmann scale) 4단계 안면마비가 관찰되었고 이 후 외래 추적기간 동안 안면마비가 지속되었다. 장시간 침샘 조직의 염증이 지속된 상태인 경우는 종양 수술에 비해 안면 신경과의 유착이 심하기 때문에, 후이개 접근법을 통해 이하 선을 절개하는 경우 신경 확인 및 박리에 더 주의가 필요할 것으로 보인다.

본 연구에서는 외부절개가 필요한 경우에 후이개절개를 통 해서만 수술을 진행하였으나, 만약 변형된 Blair 절개법을 시 행했을 경우 합병증을 줄일 수 있었을 지 고찰해보았을 때, Blair 절개법은 후이개절개에 비해 들어올려야 하는 피판의 범위가 작기 때문에 수술 후 회복기간을 단축시킬 수 있겠으 나, 합병증은 타석증 이환 기간, 그리고 염증의 심한 정도와 더 연관이 높은 것으로 보이기 때문에 변형된 Blair 절개법을
통해 수술하였을 때 합병증 예방에 큰 이득은 없을 것으로 생각된다.

5명의 환자에서 수술 전후에 타액관 조영 자기공명영상촬 영을 시행하였으며, 수술 전에는 타석에 의해 타액 분비가 막 혀 타석보다 근위부가 확장되어 있고, 수술 후에는 타액분비 가 정상화되어 타액관이 확장이 감소되는 전형적인 소견을 관찰할 수 있다(Fig. 4). 수술 전후에 모두 영상을 촬영한 환 자의 수가 적어 타액관 크기 측정을 통한 정량적 크기의 비교 분석은 시행하지 않았다. 추후 전향적 연구를 통해 추가 연 구가 필요하다고 판단된다. 또한 본 연구는 타석의 위치와 크 기 및 술자의 경험에 따라 수술법을 결정하였기에 선택편향 (selection bias)이 존재하며, 각 치료군 간의 치료 성적과 합 병증 역시 객관적으로 비교할 수 없었다. 추후 동일 부위의 
타석에 대한 전향적 연구를 통해 각 수술법의 장단점을 비교 하는 추가적인 연구가 필요할 것으로 사료된다.

본 연구를 통해 이하선 타석증의 다양한 수술적 치료법을 소개하고 특히 타액선 내시경의 활용법과 유용성에 대해 확 인하고자 하였다. 이하선 타석의 제거 시 타석의 위치, 크기를 고려하여 적절한 수술 방법을 선택하여 정상 이하선 조직을 최대한 보존하고, 수술 후 합병증을 줄일 수 있다. 원위부 타 석의 경우 크기가 큰 경우는 구강점막 절개를 동시에 시행하 여 제거하는 것이 좋으며, 근위부 및 이하선 내부에 존재하는 타석은 타액선 내시경을 이용하여 위치를 특정한 후 후이개 접근법을 통해 제거하는 것이 유리하다. 후이개접근법을 통 한 수술을 시행하는 경우에는 타석의 위치에 따라 이하선을 절개할 필요가 있을수 있으며, 따라서 수술 전에 타액루, 타 액선관 협착, 안면마비 발생 가능성에 대해 충분한 사전 동의 가 필요할 것으로 사료된다. 타액선 내시경술을 이용하여 다 양한 이하선 타석증을 제거하는 것이 가능하며, 수술 후 타 액선 보존을 통한 기능 유지 및 증상 개선에 유용한 술식으 로 판단된다.

\section{Acknowledgments}

This work was supported by the Basic Science Research Program through the National Research Foundation funded by the Ministry of Science and ICT (NRF-2018R1A2B3004269), Republic of Korea.

\section{Author Contribution}

Conceptualization: Jae-Yol Lim. Data curation: Yu Tae Jeon, Jihoon Choi, Juha Park. Formal analysis: Jae-Yol Lim. Methodology: Yu Tae Jeon. Supervision: Jae-Yol Lim. Visualization: Yu Tae Jeon. Writing — original draft: Yu Tae Jeon. Writing_review \& editing: Yu Tae Jeon, Jihoon Choi, Young Min Park, Jae-Yol Lim.

\section{ORCIDs}

Jae-Yol Lim
Yutae Jeon

Jihoon Choi

Juha Park

Young Min Park https://orcid.org/0000-0001-7718-4520

https://orcid.org/0000-0002-0465-3098

https://orcid.org/0000-0001-7482-8298

https://orcid.org/0000-0002-7593-8461

\section{REFERENCES}

1) Sigismund PE, Zenk J, Koch M, Schapher M, Rudes M, Iro H. Nearly 3,000 salivary stones: Some clinical and epidemiologic aspects. Laryngoscope 2015;125(8):1879-82.

2) Choi YC, Shim JH, Kang JJ, Choi HS. Case report: Parotid sialolithiasis. Korean J Otorhinolaryngol-Head Neck Surg 2007; 50(9):829-32.

3) Strychowsky JE, Sommer DD, Gupta MK, Cohen N, Nahlieli O. Sialendoscopy for the management of obstructive salivary gland disease: A systematic review and meta-analysis. Arch Otolaryngol Head Neck Surg 2012;138(6):541-7.

4) Nahlieli O, London D, Zagury A, Eliav E. Combined approach to impacted parotid stones. J Oral Maxillofac Surg 2002;60(12):141823.

5) McGurk M, MacBean AD, Fan KF, Sproat C, Darwish C. Endoscopically assisted operative retrieval of parotid stones. Br J OralMaxillofac Surg 2006;44(2):157-60.

6) Nahlieli O. Complications of sialendoscopy: Personal experience, literature analysis, and suggestions. J Oral Maxillofac Surg 2015; 73(1):75-80

7) Walvekar RR, Razfar A, Carrau RL, Schaitkin B. Sialendoscopy and associated complications: A preliminary experience. Laryngoscope 2008;118(5):776-9.

8) Eun YG, Chung DH, Kwon KH. Advantages of intraoral removal over submandibular gland resection for proximal submandibular stones: A prospective randomized study. Laryngoscope 2010; 120(11):2189-92.

9) Iro H, Zenk J, Escudier MP, Nahlieli O, Capaccio P, Katz P, et al. Outcome of minimally invasive management of salivary calculi in 4,691 patients. Laryngoscope 2009;119(2):263-8.

10) Witt RL, Iro H, Koch M, McGurk M, Nahlieli O, Zenk J. Minimally invasive options for salivary calculi. Laryngoscope 2012;122(6): 1306-11. 